\title{
ELISA reagents for potato virus $Y$ strains with significantly low non-specific reactions
}

\author{
AARNE KURPPA \\ Department of Plant Pathology, University of Helsinki, \\ SF-00710 HELSINKI 71, Finland
}

KIRSI KORHONEN

Labsystems Ltd, Pultitie 8-11, SF-00810 HELSINKI 81, Finland

\begin{abstract}
High titered and highly virus-specific antisera to selected PVY॰ and PVYn antigens and their mixture were produced in rabbits. Immunoglobulins purified from the antisera with the protein A method and their enzyme conjugates had very strong virus-specific but no non-specific reactions in the ELISA test. Their homologous reactions to the antigens were stronger than heterologous but any PVY isolate could be identified in a potato leaf sample with the dilutions between $10^{-2}$ and $10^{-3}$ and in a sample from sprouted tubers with secondary infection diluted between $10^{-1}$ and $10^{-2}$.
\end{abstract}

\section{Introduction}

The ELISA test (Enzyme-linked immunosorbent assay) (CLARK \& ADAMS 1977) is now routinely used in many countries for potato virus identification. The main advantage of the test is its ability to identify potato leaf roll virus (PLRV) (CASPER 1977) and most other viruses in tuber sap (de BоKX et al. 1980, Daniel \& Hunnius 1980, Banttari \& FRANK 1982).

The problems in the test caused by too high specificity or distinct virus strains have been reported by MAAT and de BoKx (1978), LiU and Duffus (1982) and KurPPA (1983). Non-specific reactions in the ELISA test have been widely found particularly when viruses are identified in potato tubers. Nonspecific absorbance values from healthy tubers have varied depending on the cultivar tested and the physiological stage of the tuber (de BoKx et al. 1980, TAMADA \& HARriSON 1980). The aim of this study was to prepare polyclonal immunoglobulin reagents to potato virus $\mathrm{Y}$ strains $\mathrm{Y}^{\circ}$ and $\mathrm{Y}^{\mathrm{n}}$ to be used in the ELISA method with high virus-speci- 
ficity but without too high strain or isolate specificity.

\section{Materials and methods}

The antigens for the study were selected according to the previous study of PVY diversity in Finland by KURPPA (1983). The selected isolates of $\mathrm{PVY}^{\circ}$ and $\mathrm{PVY}^{\mathrm{n}}$ strains were serologically more related to the heterologous strain than which is normal. Also a purified mixture $(1: 1)$ of the antigens was used as an immunogen in antiserum production.

The antigen of the $\mathrm{PVY}^{\circ}$ strain was purified from the leaves of Nicotiana glutinosa and the antigen of $\mathrm{PVY}^{\mathrm{n}}$ strain from the leaves of $N$. tabacum cv. Samsun with systemic infection. The purification method of LEISER \& Richter (1978) was used with minor modifications. The antigens were finally purified in the density gradient centrifugation in $5-35 \%(w / v)$ of sucrose just before they were needed for the immunization into the rabbits.

The rabbits were immunized with subcutaneous injections of $200 \mu \mathrm{g}$ of virus in 500 $\mu \mathrm{l}$ buffer mixed with equal volume of Freund's adjuvant. Complete adjuvant was used for the first injection and incomplete for the following injections. The procedure for immunization and the titers of the antisera are presented in the table 1.

Antiserum collection was started four weeks from the first injection and after that the rabbits were bled at about $2-3$ weeks intervals. $20-30 \mathrm{ml}$ of blood was taken at each bleeding.

The titers of the antisera were determined with the microprecipitin test against purified virus preparates and with the agglutination test against healthy and infected tobacco sap. The properties of the antisera for the preparation of reagents for the ELISA test were determined several times during the antiserum production procedure. Total immunoglobulin fractions were separated from the antisera using protein A-Sepharose CL 4B and Sephadex G-25 gels and FRAG-300, UV-Z and REC-2 chromatographic equipments (Pharmasia, Sweden). The enzyme conjugates were prepared as described by Clark \& Adams (1977). For the EliSA test EIA-Grade Cuvette blocks (Labsystems Ltd, Helsinki) and Microstrip plates (Eflab, Helsinki) were used.

For the readings of test results the photometers (FP-9 and Titertek Multiscan, Eflab) were calibrated either using distilled water to show all possible non-specificity in the tests or using fresh substrate solution to obtain a comparable 0 -standard for the routine test readings. The virus-specific reaction was calculated as an absorbance ratio of virus infected and healthy test samples (see KURPPA 1983). The value of each reagent was widely tested in routine tests of healthy potato tuber and leaf samples and similar samples infected with known PVY isolates. Also field material of several potato cultivars were tested.

Table 1. Injection and sampling schedules, and homologous titers of the antisera as determined with the microprecipitin test. $1=$ injection

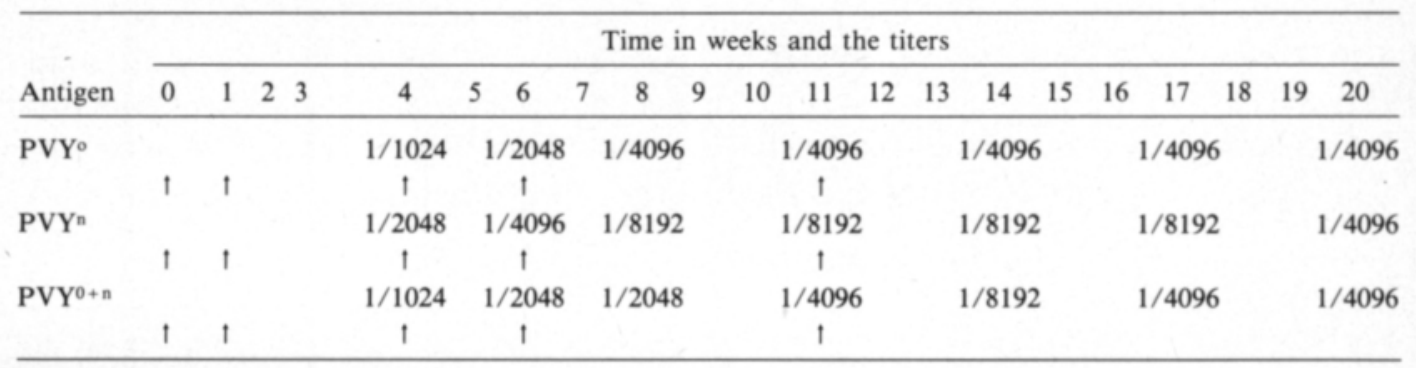




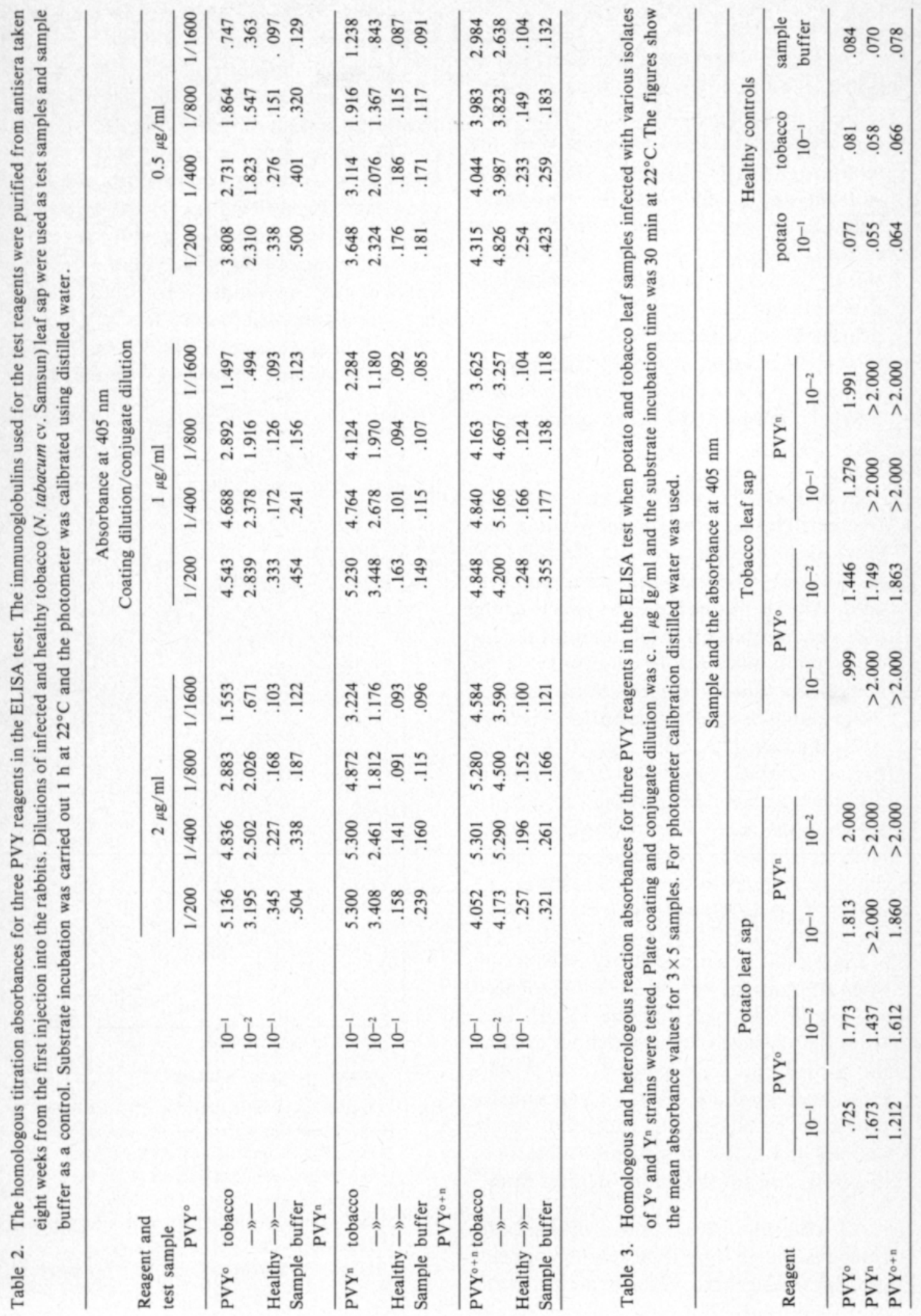




\section{Results}

The titers of the antisera produced reached high level within four weeks from the first injection. All homologous titers were 1/1024 and heterologous $1 / 512$ or higher when determined with the microprecipitin test or with the agglutination test. No reaction to host protein was detected. The titers rose further during the following weeks and the values of $1 / 8192$ or $1 / 4096$, respectively, were reached. The titers of the antisera remained high for several weeks after injections (Table 1) and the non-specific reaction to plant sap remained significantly low during the following weeks of the immunization program.

In addition the purified immunoglobulin fractions ( $\mathrm{Ig}$ ) and their enzyme conjugates (EIg) showed high virus-specificity in the ELISA test when suitable dilutions were used. Almost no reaction was found to the host species from which the antigens for the antiserum production were purified and the absorbance values in the tests often remained lower than those for sample buffer (Table 2). All Ig dilutions (2, 1 and $0.5 \mu \mathrm{g}$ of $\mathrm{Ig} / \mathrm{ml}$ and EIg dilutions $(1 / 200,1 / 400$ and $1 / 800)$ in different combinations gave high absorbance values in the tests but the highest specificity was found when Ig concentration of $1 \mu \mathrm{g} / \mathrm{ml}$ and EIg dilutions of $1 / 400$ or $1 / 800$ (c. 2.5 and $1.25 \mu \mathrm{g} \mathrm{Ig} / \mathrm{ml}$ ) were used.

Significant strain specificity was found when PVY strains were identified in tobacco and potato leaf sap with the ELISA test. However, the heterologous reactions of all of the test reagents were strong (Table 3). The virus concentration of $\mathrm{Y}^{\mathrm{n}}$ strain samples proved to be higher than that of $\mathrm{Y}^{\circ}$ strain samples and higher absorbance values were therefore read for the former in most cases.

All reagents gave strong virus-specific reactions and no significant reaction to plant proteins was detected. If the photometer was calibrated using fresh substrate solution the absorbance values for healthy plant samples were equal to \pm 0.000 .

In serial dilutions of potato leaf sap with secondary infection PVY could be reliably detected in a dilution of $10^{-2}$ or $10^{-3}$ (Fig. 1). The test reagents for the $Y^{n}$ strain were found to be extremely virus-specific and no significant background problems existed, even if substrate incubation times of several hours were used. Absorbance values were often obtained for samples of $10^{-1}$ dilution that were higher than for undiluted samples.

In potato tuber samples with secondary infection PVY could be reliably detected in a

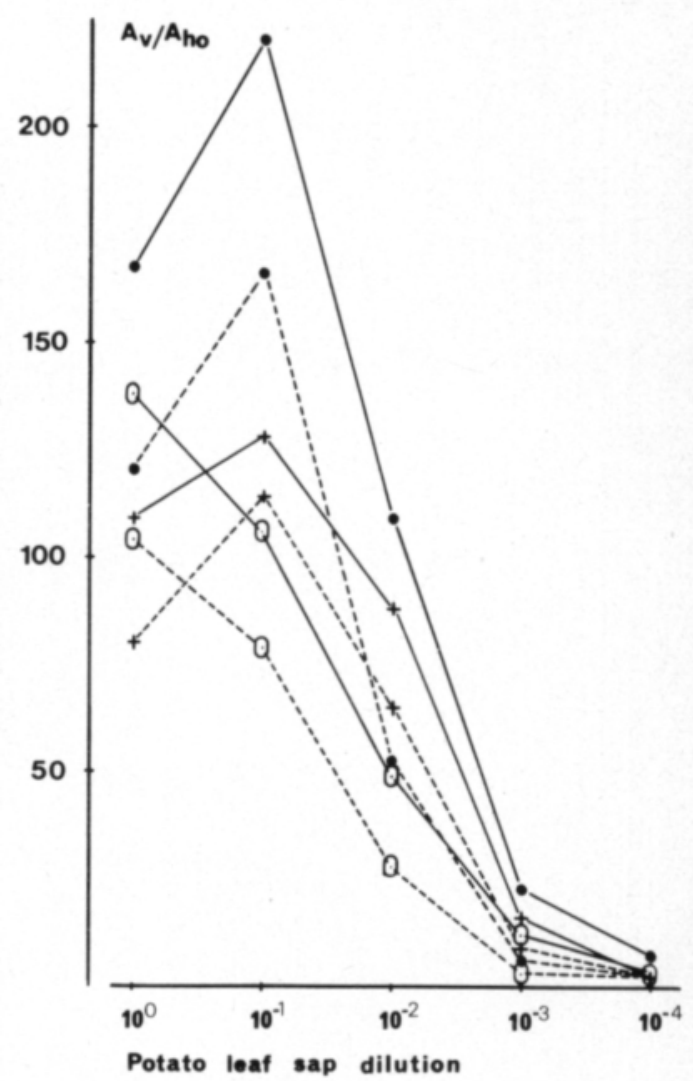

Fig. 1. Specific reaction ratios for PVY-ELISA-reagents calculated from the absorbance values of undiluted and diluted PVY infected $\left(\mathbf{A}_{v}\right)$ and healthy undiluted samples $\left(A_{\mathrm{ho}}\right)$. Substrate incubation was carried out for $30 \mathrm{~min}$ at $22^{\circ} \mathrm{C}$. The photometer was calibrated using fresh substrate solution.

$$
\begin{aligned}
& \text { - } \bullet=\mathrm{Y}^{\mathrm{n}} \text { reagent }-\mathrm{Y}^{\mathrm{n}} \text { samples } \\
& \circ \circ \mathrm{O}=\mathrm{Y}^{\circ} \text { reagent } \quad \ldots .-\mathrm{Y}^{\circ} \text { samples } \\
& +++=\mathrm{Y}^{\circ+\mathrm{n}} \text { reagent }
\end{aligned}
$$


dilution of $10^{-1}$ or $10^{-2}$ (Fig. 2). Absorbance readings higher than 2.0 were often obtained for the samples with $10^{-1}$ dilution when routine method with one hour's substrate incubation time was used. No problems arose from the low virus concentration or nonspecific reactions when presprouted tubers of several potato cultivars were tested. The variation in the absorbance values for different virus isolates tested in the tubers

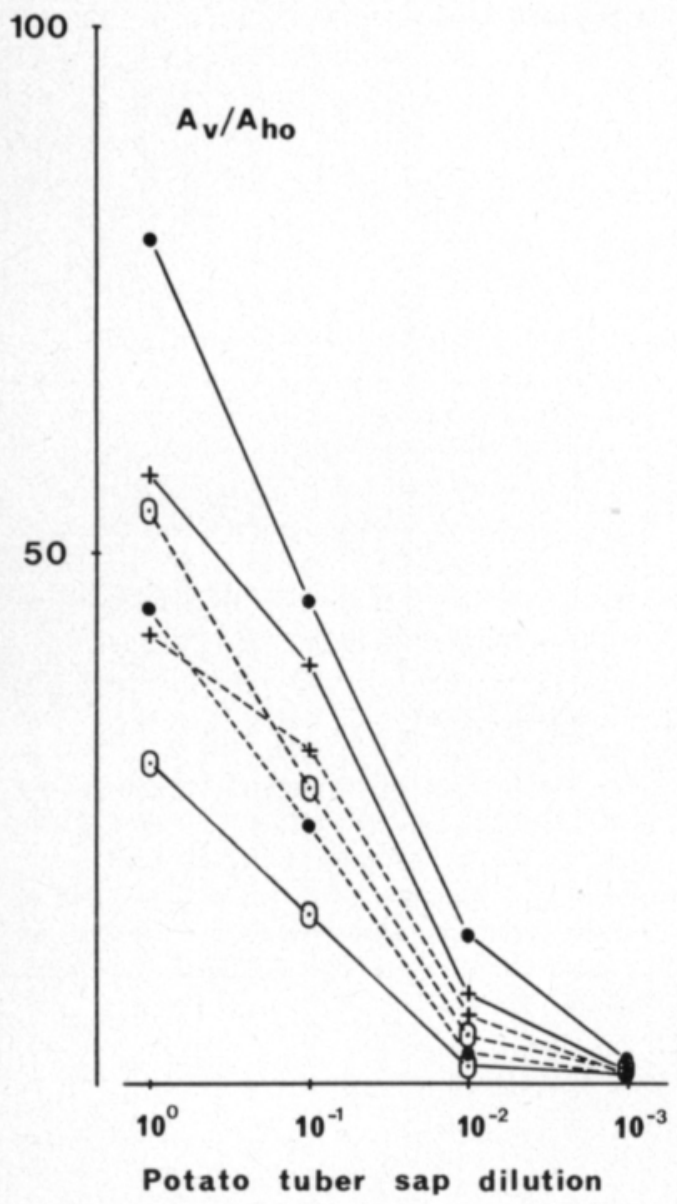

Fig. 2. Specific reaction ratios for PVY-ELISA-reagents calculated from the absorbance values of undiluted and diluted potato tuber samples with secondary PVY infection $\left(\mathrm{A}_{\mathrm{v}}\right)$ and healthy undiluted tuber samples $\left(A_{\text {ho }}\right)$. Substrate incubation was carried out for $30 \mathrm{~min}$ at $22^{\circ} \mathrm{C}$. The photometer was calibrated using fresh substrate solution.

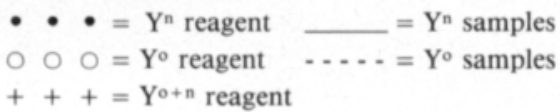

was smaller than if the viruses were tested in leaf samples. However, the absorbance values for any healthy sample always remained low and no significant variation between comparable samples was found.

\section{Discussion}

The high virus-specificity in the antisera produced by low dosage injections into rabbits agree with the results of RiCHTER et al. (1979) and ClaRKE (1981). Also the titers of the antisera were high compared to the results obtained with subcutaneous injections into rabbits.

No significant disadvantages were found when using the total immunoglobulin fraction instead of the recommended $\gamma$-globulin fraction (Clark \& Adams 1977) for the ELISA test.

The selection of the known virus isolates for the antiserum production yielded antisera with the properties desired and the restricted strain or isolate specificity reported by MAAT and de Вокx (1978) was avoided. The absorbance values obtained in the tests were primarily related to the virus concentration in the sample.

The reason for the higher absorbance values from the leaf samples after dilution compared with undiluted samples was possibly due to particle aggregation in the undiluted sap. In dense aggregates fewer serologically active determinants are free to react with the antibodies than in the solutions containing non aggregated particles in equal or even in lower concentrations. Similar phenomen have previously been reported (KURPPA 1983).

The specific absorbance values calculated for the ELISA test reagents (specific immunoglobulin and its conjugate) made of the antisera produced in this study were remarkably higher than those calculated from the results of MAAT and de BокX (1978) and DAniel and Hunnius (1980). They were also higher than earlier reported by KURPPA (1983) or calculated from the readings ob- 
tained with commercially available test reagents in this study.

The monoclonal antibody preparates for the ELISA test have some obvious advantages over polyclonal preparates when used for specific purposes. In the identification of potato viruses, excluding PLRV, the desired reaction sensitivity and broad specificity to the strains and isolates is easily obtained if the virus antigens for the antiserum production are carefully studied and selected. The serologic suitability, high virus-specificity and the lack of non-specific reactions determine the value of an antiserum preparate. From this study it is clear that highly virus-specific but not too strain-specific polyclonal antibodies are desirable for the identification of potato viruses with the ELISA technique. For good results, carefully selected and purified virus antigens are necessary and low dosage injections into rabbits are recommended.

Acknowledgements: The financial support received from the Finnish Academy is gratefully acknowledged.

\section{References}

Banttari, E.E. \& Franc, G.D. 1982. Enzyme-linked immunosorbent assay with single or combined antisera for viruses $\mathrm{S}$ and $\mathrm{X}$ in potato tubers and plants. Am. Potato J. 59: 375-387.

Bokx, J.A. de, Piron, P.G. \& Cother, E. 1980. Enzyme-linked immunosorbent assay (ELISA) for the detection of potato viruses $\mathrm{S}$ and $\mathrm{M}$ in potato tubers. Neth. J. Pl. Path. 86: 285-290.

CASPER, R. 1977. Detection of potato leafroll virus in potato and in Physalis floridana by enzyme-linked immunosorbent assay (ELISA). Phytopath. Z. 90: $364-368$.

Clank, M.F. \& Adams, A.N. 1977. Characteristics of the micro-plate method of enzyme-linked immunosorbent assay for the detection of plant viruses. J. Gen. Virol. 34: 475-483.

Clarke, R.G. 1981. Potato leafroll virus purification and antiserum preparation for enzyme-linked immunosorbent assays. Am. Potato J. 58: 291-298.

Daniel, G. \& Hunnius, W. 1980. Nachweis der Kartoffelviren $\mathrm{M}, \mathrm{S}, \mathrm{X}$ und $\mathrm{Y}$ in Pressäften sekundärinfizierten Kartoffelpflanzen mit ELISA (enzyme-linked immunosorbent assay). Gesunde Pfl. 32: 118-127.

Kurppa, A. 1983. Potato viruses in Finland and their identification. J. Scient. Agric. Soc. Finl. 55: $183-301$.
Leiser, R.-M. \& RıCHTER, J. 1978. Reinigung und einige Eigenschaften des Kartoffel-Y-Virus. Arch. Phytopath. Pfl.schutz. 14: 337-350.

Liu, H.-Y. \& Durfus, J. 1982. The differentiation of distinct serotypes from potato leaf roll affected plants by "enzyme-linked immunosorbent assay (ELISA). Am. Potato J. 59: 476.

MAAт, D.Z. \& Boкx, J.A. de 1978. Enzyme-linked immunosorbent assay (ELISA) for the detection of potato viruses $\mathrm{A}$ and $\mathrm{Y}$ in potato leaves and sprouts. Neth. J. Pl. Path. 84: 167-174.

Richter, J., Leiser, R.-M., Proll, E. \& Doring, U. 1979. Versuche zur Differenzierung von Stämmen der Kartoffelviren X, S, M und Y an Hand ihrer Immunogenität. Arch. Phytopath. Pfl.schutz 15: 13-20.

TAMADA; T. \& Harrison, B.D. 1980. Application of enzyme-linked immunosorbent assay to the detection of potato leafroll virus in potato tubers. Ann. Appl. Biol. 96: 67-78.

Ms received December 13, 1983 


\section{SELOSTUS}

\section{Luotettavasti toimivia vasta-ainereagensseja perunan Y-viruksen määrittämiseen ELISA- menetelmän avulla}

\author{
Aarne Kurppa \\ Helsingin yliopisto, kasvipatologian laitos, \\ 00710 Helsinki 71
}

\section{Kirsi Korhonen}

Labsystems $\mathrm{Oy}$,

Pulttitie 8-11, 00810 Helsinki 81

Helsingin yliopiston kasvipatologian laitoksen ja Labsystems Oy:n yhteistutkimuksena valmistettiin perunan Y-viruksen vasta-aineita ELISA-menetelmăn (enzymelinked immunosorbent assay) avulla tehtäviă rutiinimäărityksiä varten. Vasta-aineiden avulla voitiin osoittaa luotettavasti erittäin alhaisia viruskonsentraatioita erilaisista kasvinäytteistä, koska ne eivät reagoineet vastaaviin terveisiin năytteisiin.

Vasta-aineet valmistettiin maassamme eristetyille perusteellisesti tutkituille $\mathrm{Y}$-viruksen rotujen $\mathrm{Y}^{\circ}$ ja $\mathrm{Y}^{\mathrm{n}}$ isolaateille, joiden oli todettu reagoivan keskimäăräistä voimakkaammin vieraan rodun vasta-aineisiin. Myős virusrotuseokselle valmistettiin vasta-aine.

Adjuvanttiin sekoitettu virusantigeeni injektoitiin kanien selkänahan alle. Menettely todettiin helpoksi ja koe-eläinten terveydentilan kannalta erittăin hyvăksi.
Vasta-aineseerumien tiitterit kohosivat korkeiksi (1/4096-1/8192) pienistä $200 \mu \mathrm{g}: n$ injektointiannoksista huolimatta. ELISA-menetelmän mäăritysreagenssien valmistamiseen käytettiin $\gamma$-globuliinifraktion sijasta kokonaisimmunoglobuliinifraktiota, joka erotettiin raakaseerumista proteiini-A-menetelmää käyttäen.

Reagensseilla voitiin tãysin luotettavasti mäărittäă perunan Y-virus $10^{-2}$ tai $10^{-3}$ laimennetusta perunan lehtimehusta ja $10^{-1}$ tai $10^{-2}$ laimennetusta hieman idätetyn mukulan mehusta. Perunalajike ei vaikuttanut maaăritystulosten luotettavuuteen.

Tutkimuksessa valmistetut testireagenssit toimivat luotettavammin kuin maassamme aikaisemmin valmistetut tai ulkomaiset myytävänä olevat vastaavat reagenssit. Valmistetut uudet määritysvasta-aineet sopivat erityisesti Suomen oloihin. 